\title{
PELAKSANAAN UNDANG-UNDANG NOMOR 23 TAHUN 2011 TENTANG PENGELOLAAN ZAKAT (Studi Kasus di BAZ Kabupaten Nganjuk)
}

\author{
Oleh \\ Dewi Fitrotus Sa'diyah ${ }^{1}$ \\ Bhaswarendra Guntur ${ }^{2}$ \\ Institut Agama Islam Pangeran Diponegoro Nganjuk
}

\begin{abstract}
Zakat is one of the Five Pillars of Islam, so with the issuance of Law Number 23 of 2011 concerning Management of Zakat by the government, a zakat management organization is formed, namely the Zakat Amil Agency (BAZ) formed by the government and the Amil Zakat Institution (LAZ) confirmed by the government. This study uses an empirical juridical approach. In collecting data and legal materials, both primary and secondary, cases are collected through interviews and study of legal documents, while the analytical techniques are carried out qualitatively. The composition of the BAZ Management of Nganjuk Regency consists of the Advisory Board, the Supervisory Commission and the Implementing Body. In terms of collecting zakat, this is done by UPZ in various institutions, both government and private institutions, after which it is deposited to the $B A Z$ of the Nganjuk Regency to be utilized. In the Nganjuk Regency $B A Z$, the utilization of the results of zakat receipts is in accordance with the provisions of religion, which includes eight ashnaf. In carrying out zakat management, this agency encountered various kinds of obstacles faced. Therefore there are several attempts to respond to various problems.
\end{abstract}

Keywords: Law, Zakat Management, Amil Zakat Agency

\begin{abstract}
Abstrak
Zakat merupakan salah satu dari Rukun Islam, maka dengan dikeluarkannya Undang-Undang Nomor 23 Tahun 2011 tentang Pengelolaan Zakat oleh pemerintah, dibentuklah organisasi pengelolaan zakat yaitu Badan Amil Zakat (BAZ) yang dibentuk oleh pemerintah dan Lembaga Amil Zakat (LAZ) yang dikukuhkan oleh
\end{abstract}


pemerintah. Penelitian ini menggunakan pendekatan yuridis empiris. Dalam pengumpulan data dan bahan hukum, baik primer maupun sekunder, kasus yang dikumpulkan melalui wawancara dan studi dokumen-dokumen hukum,sedangkan tekhnik analisis dilakukan secara kualitatif. Susunan Pengurus BAZ Kabupaten Nganjuk terdiri dari Dewan Pertimbangan, Komisi Pengawas dan BadanPelaksana. Dalam hal pengumpulan zakat, hal ini dilakukan oleh UPZ di berbagai instansi, baik instansi pemerintah maupun swasta, setelah itu disetorkan kepada BAZ Kabupaten Nganjuk untuk didayagunakan. Di BAZ Kabupaten Nganjuk, pendayagunaan hasil penerimaan zakat telah sesuai dengan ketentuan agama yaitu meliputi delapan ashnaf. Di dalam melakukan pengelolaan zakat, badan ini menemui berbagai macam kendala yang dihadapi. Oleh karena itu ada beberapa upaya untuk merespon berbagai masalah yang ada.

Kata Kunci: Undang-Undang, Pengelolaan Zakat, Badan Amil Zakat

\section{Pendahuluan}

Syariat Islam sebagai ajaran wahyu dapat dipetakan menjadi dua kelompok. Pertama, ajaran Islam yang memiliki hubungan vertikal (Hablum Minalloh), yaitu antara manusia dengan tuhan. Kedua, ajaran Islam yang memiliki hubugan horizontal (Hablum Minannas), kaitannya bukan hanya antara manusia dengan tuhan, melainkan memiliki hubungan sosial. Salah satu ajaran Islam yang memiliki hubungan sosial adalah zakat.

Problem kemiskinan merupakan masalah sosial yang niscaya hadir dalam kehidupan manusia. Upaya untuk mengatasi kemiskinan pun tidak mudah. Banyak program-program yang dilaksanakan pemerintah diantaranya seperti pembagian Beras Miskin (Raskin) dan Bantuan Langsung Tunai (BLT). Namun upaya pemerintah melalui beragam program tersebut belum bisa mengatasi problem kemiskinan

Kemiskinan sesungguhnya tidak akan bisa dihilangkan, karena sudah menjadi sunnatullah. Solusi yang bisa atau mungkin dilakukan adalah dengan berusaha mengeliminasi atau memperkecil tingkat kemiskinan itu. Salah satunya adalah dengan mengaplikasikan solusi dari ajaran Islam. Islam pada dasarnya memiliki solusi yang bersifat imperatif untuk mengatasi problem klasik tersebut. Solusi 
yang mampu mengurangi beban hidup bagi orang yang tidak mampu (fakir miskin) dan menjadi bagian ibadah bagi orang yang mampu (kaya).

Solusi tersebut adalah zakat. Zakat sebagai salah satu rukun Islam, selain memiliki dimensi ilahiyyah, juga berdimensi insaniyyah. Artinya adalah ibadah zakat selain merupakan bentuk ibadah antara manusia dengan Tuhan-Nya, zakat juga termasuk ibadah yang sifatnya memiliki dimensi sosial, yang tidak hanya merupakan ritual individu semata, melainkan juga ibadah yang memiliki dampak sosial yang akan sangat membantu dhu'afa (orang-orang lemah) dari ketidakmampuan dalam kemiskinan.

Jika pendaftar calon haji telah melebihi kuota, tidak demikian halnya dengan pendaftar sebagai muzakki (orang yang berzakat). Zakat sebagai pilar ekonomi serta pondasi pembangunan masyarakat berperan sangat penting untuk mengatasi masalah bangsa. Ditinjau dari aspek ekonomi, mobilisasi zakat merupakan sebuah himpunan dana yg besar. Dana ini sangat dibutuhkan untuk mengatasi kebutuhan ekonomi para Mustahiq (orang yang berhak menerima zakat).

Selain itu, kadang jumlah mustahiq (orang yang berhak menerima zakat) di daerah tertentu terbilang tidak begitu banyak dan tidak seimbang dengan hasil pengumpulan dan pendistribusian zakatnya. Pada akhirnya orang yang semestinya tidak berhak menerima zakat, tetap saja menerima pembagian zakat tersebut. Tentu praktik ini tidak sejalan dengan pesan-pesan syariat. Dalam ajaran agama Islam, pemungutan zakat sebaiknya dilakukan oleh pemerintah, sebagaimana firman Allah dalam Al Qur’an surat At Taubah : 103

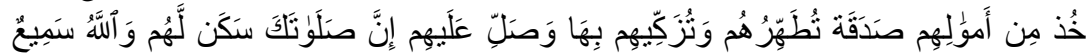
عَليمّ r. Artinya : "Ambillah zakat dari sebagian harta mereka dengan zakat itu kamu membersihkan dan menyucikan mereka dan mendoakan mereka. Sesungguhnya doa kami itu (menjadi) 
ketentraman jiwa bagi mereka. Allah Maha Mendengar lagi Maha Mengetahui ${ }^{, 44}$

Tujuan pemungutan zakat dilakukan oleh pemerintah adalah agar para pemberi zakat tidak merasa bahwa yang dikeluarkan itu sebagai kebaikan hati, bukan kewajiban dan para fakir tidak merasa berhutang kepada orang kaya. Selain itu terdapat beberapa keuntungan apabila zakat dipungut oleh pemerintah, yaitu : a) Para wajib zakat lebih disiplin dalam menunaikan kewajibannya dan fakir miskin lebih terjamin haknya; b) Perasaan fakir miskin lebih dapat terjaga, tidak merasa seperti orang yang meminta-minta; c) Pembagian zakat akan menjadi lebih tertib; d) Zakat yang diperuntukkan bagi kepentingan umum seperti sabillilah misalnya dapat disalurkan dengan baik karena pemerintah lebih mengetahui sasaran pemanfaatannya.

Nilai-nilai yang terkandung dalam kewajiban zakat adalah sama dengan salah satu tujuan nasional Negara Republik Indonesia yang diamanatkan dalam Pembukaan Undang-Undang Dasar 1945 pasal 34 (ayat 1) "Yaitu Negara memiliki kewajiban untuk memelihara fakir miskin dan anak - anak terlantar serta memperdayakan mereka". Dengan pengelolaan yang baik, zakat merupakan sumber dana yang potensial yang dapat dimanfaatkan untuk memajukan kesejateraan umum bagi seluruh masyarakat Indonesia. Untuk dapat menjamin terlaksananya pengelolaan zakat yang baik diperlukan adanya peraturan perundang-undangan yang mengatur mengenai pengelolaan zakat.

Setelah lebih dari 10 tahun UU No;38 tahun 1999 tentang pengelolaan zakat dinilai tidak optimal, muncul dorongan untuk mengubah, memperjelas dan mengarah pada tujuan yang lebih terukur. Pembaharuan Undang-Undang Pengelolaan Zakat merupakan terobosan politik untuk memperbaiki system koordinasi antarorganisasi pengelola zakatyang belum berjalan secara efektif selama ini , baik secara vertical ,horizontal maupun diagonal.

${ }^{44}$ Departemen Agama, Al Qur'an dan Terjemah, (Semarang : CV Al Waad, 2013) 


\section{Metode Penelitian}

Penelitian dapat didefinisikan sebagai usaha untuk menemukan, mengembangkan dan menguji kebenaran suatu pengetahuan, usaha mana dilakukan dengan penggunaan metode ilmiah. ${ }^{45}$ Sedangkan yang dimaksud dengan penelitian hukum adalah suatu kegiatan ilmiah yang didasarkan pada metode, sistematika dan pemikiran tertentu, yang bertujuan untuk mempelajari satu atau beberapa gejala hukum tertentu, dengan jalan menganalisanya. Kecuali itu, diadakan juga pemeriksaan secara mendalam terhadap fakta tersebut, untuk kemudian mengusahakan pemecah atas permasalahan-permasalahan yang timbul di dalam gejala yang bersangkutan.

Metode Pendekatan yang digunakan dalam penelitian ini adalah pendekatan yuridis empiris. Pendekatan yuridis digunakan untuk menganalisis berbagai peraturan perundang-undangan. Sedangkan pendekatan empiris digunakan untuk menganalisis hukum yang dilihat sebagai perilaku masyarakat yang berpola dalam kehidupan masyarakat yang selalu berinteraksi dan berhubungan dalam aspek kemasyarakat. Metode Pengumpulan Data yang digunakan dalam penelitian ini adalah Metode Kualitatif. Maka dari data yang telah dikumpulkan secara lengkap dan telah di teliti keabsahannya dan dinyatakan valid, lalu diproses melalui langkahlangkah yang bersifat umum, petama reduksi data adalah data yang diperoleh di lapangan ditulis / diketik dalam bentuk laporan yang terperinci. Laporan tersebut direduksi, dirangkum, dipilih hal-hal yang pokok, difokuskan pada hal-hal yang penting serta dicari tema dan polanya. Kedua, mengambil kesimpulan dan verifikasi, yaitu data yang telah terkumpul dan telah direduksi, diusahakan untuk dicari makna, pola, hubungan, persamaan dan hal-hal yang sering timbul sehingga kemudian dapat disimpulkan.

Metode Analisis Data yang digunakan dalam penelitian ini adalah Metode Analisisi Kualitatif. Dari data yang telah dikumpulkan

\footnotetext{
${ }^{45}$ Sutrisno Hadi, Metodologi Research, Jilid I cet. Ke-24 (Yogyakarta : Andi Offset, 2013), hal 4
} 
secara lengkap dan telah di teliti keabsahannya dan dinyatakan valid, lalu diproses melalui langkah-langkah yang bersifat umum, yakni :Reduksi data adalah data yang diperoleh di lapangan ditulis / diketik dalam bentuk laporan yang terperinci. Laporan tersebut direduksi, dirangkum, dipilih hal-hal yang pokok, difokuskan pada hal-hal yang penting serta dicari tema dan polanya. Mengambil kesimpulan dan verifikasi, yaitu data yang telah terkumpul dan telah direduksi, diusahakan untuk dicari makna, pola, hubungan, persamaan dan halhal yang sering timbul sehingga kemudian dapat disimpulkan.

\section{Hasil Dan Pembahasan}

\section{Undang - Undang No 23 Tahun 2011 Tentang Pengelolaan Zakat}

Zakat telah manjadi salah satu sumber dana yang penting bagi perkembangan agama Islam sejak masuknya Islam di Indonesia. Pada masa penjajahan Belanda, Pemerintah Kolonial mengeluarkan Bijblad Nomor 1892 tanggal 4 Agustus 1893 yang berisi tentang kebijakan Pemerintah Kolonial mengenai zakat.Belanda melarang petugas agama dan perintah untuk mengumpulkan zakat. Kemudian pada tanggal 6 Februari 1905 dikeluarkan Bijblad Nomor 6200 yang berisi tentang pelarangan bagi seorang pegawai dan priyayi pribumi untuk membantu pelaksanaan zakat. Hal ini bertujuan untuk semakin melemahkan kekuatan rakyat yang bersumber dari zakat tersebut.Tahun 1943(MIAI) membentuk Baitul Maaluntuk mengkoordinir zakat. ${ }^{46}$

Setelah kemerdekaan Indonesia,perkembangan zakat menjadi lebih maju.Perhatian pemerintah terhadap lembaga zakat semakin meningkat pada tahun 1968. Yaitu dengan dikeluarkannya Peraturan Menteri Agama Nomor 4 dan Nomor 5 Tahun 1968, masing-masing tentang pembentukan Badan Amil Zakat dan Baitul Mal (Balai Harta Kekayaan) di tingkat pusat, propinsi, dan kabupaten/kota.

Setahun sebelumnya yaitu pada tahun 1967, pemerintah telah menyiapkan RUU Zakat yang akan diajukan kepada DPR untuk

\footnotetext{
${ }^{46}$ Kementerian Agama Standarisasi Amil Zakat Di Indonesia th 2013
} 
disahkan menjadi undang-undang. RUU tersebut disiapkan oleh Menteri Agama dengan harapan akan mendapat dukungan dari Menteri Sosial dan Menteri keuangan. Karena masalah ini erat kaitannya dengan pelaksanaannya pasal 34 UUD 1945 dan masalah pajak. Namun gagasan tersebut ditolak oleh Menteri Keuangan yang menyatakan bahwa peraturan mengenai zakat tidak perlu dituangkan dalam undang-undang, tetapi cukup dengan Peraturan Menteri Agama saja. Dengan pernyataan Menteri Keuangan tersebut, Menteri Agama mengeluarkan keputusan yang berisi tentang penundaan pelaksanaan Peraturan Menteri Agama Nomor 5/1968.

Presiden Indonesia saat itu, Presiden Suharto, pada malam peringatan Isra' Mi'raj di Istana negara tanggal 22 Oktober 1968, mengelurkan anjuran untuk menghimpun zakat secara sistematis dan terorganisasi. Bahkan secara pribadi beliau menyatakan diri bersedia menjadi 'amil zakat tingkat nasional. 5 Desember 1968 dengan dipelopori oleh Pemerintah Daerah Khusus Ibukota Jakarta Raya, yang pada waktu itu dipimpin oleh Gubernur Ali Sadikin, berdirilah Badan Amil Infaq dan Shadaqah (BASIS). Hal ini diikuti oleh berbagai propinsi di Indonesia, yaitu dengan terbentuknya Badan Amil Zakat yang bersifat semi pemerintah melalui surat keputusan Gubernur. Tahun 1969 dikeluarkanlah kepres no 44 tentang dibentunya panitia penggunaan zakat yang di ketuai oleh Manko Kesra Idham Kholid. $^{47}$

Untuk meningkatkan pembinaan terhadap BAZIS, pada tahun 1991 Menteri Dalam Negeri dan Menteri Agama mengeluarkan Keputusan Bersama No. 29 dan 47 tentang Pembinaan Badan Amil Zakat, Infaq, Shadaqah, yang diikuti dengan instruksi Menteri Dalam Negeri No.7 tahun 1991 tentang Pelaksanaan Keputusan Bersama tersebut . Kemudian pada tanggal 7 Januari 1999 dilaksanakan Musyawarah Kerja Nasional I Lembaga Pengelola ZIS dan Forum Zakat yang dibuka oleh Presiden Habibie. Salah satu hasil dari musyawarah tersebut adalah perlunya dipersiapkan UU tentang

${ }^{47}$ Kementerian Agama Standarisasi Amil Zakat DI Indonesia th 2013 
Pengelolaan Zakat. Hasil musyawarah tersebut ditindak lanjuti dengan Surat Menteri Agama No. MA/18/111/1999 mengenai permohonan persetujuan prakarsa penyusun RUU tentang Pengelolaan Zakat.

Permohonan tersebut disetujui melalui surat Menteri Sekretaris Negara RI No. B. 283/4/1999 tanggal 30 April 1999. Pembahasan mengenai RUU tentang Pengelolaan Zakat dimulai tanggal 26 Juli 1999 yaitu dengan penjelasan pemerintah yang di awali oleh Menteri Agama. Mulai tanggal 26 Agustus sampai dengan tanggal 14 September 1999 diadakan pembasan substansi RUU tentang Pengelolan Zakat dan telah di setujui oleh DPR RI dengan keputusan DPR RI Nomor 10/DPR-RI/1999. Dan melalui surat Ketua DPR RI Nomor RU.01/03529/DPR-RI/1999 tanggal 14 September 1999 disampaikan kepada Presiden untuk ditandatangani dan disahkan menjadi undang-undang. Pada tanggal 23 September 1999 diundangkan menjadi Undang-Undang Nomor 38 tahun 1999 tentang Pengelolaan Zakat. Undang-Undang Nomor 38 Tahun 1999 tentang Pengelolaan Zakat ini berisi 10 Bab dan 25 Pasal.

Tgl 17 Januari 2001 BAZNAS di bentuk melalui SK Presiden Abdurrahman Wakhid no: 8 .Tanggal 27 Oktober 2011 Amandemen UU 38 th 1999 menjadi UU no 23 th 2011.Tgl 5 Agustus 2013 oleh presiden Susilo Bambang Yudoyono ditetapkannya setiap taggal 27 Romadhon sebagai hari zakat Nasioal (HZN).Tahun 2014 terbit Peraturan Pemerintah no:14 tntang Pengelolaan zakat dan Inpres no:3 Optimaslisasi Pengumpulan Zakat.

\section{Organisasi Pengelola Zakat}

Pengelolaan zakat dalam UU No. 23 Tahun 2011 tentang Pengelolaan Zakat adalah kegiatan perencanaan, pelaksanaan, dan pengkoordinasian dalam pengumpulan dan pendistribusian dan pendayagunaan zakat. Sedangkan yang dimaksud dengan organisasi 
pengelolaan zakat adalah institusi yang bergerak di bidang pengelolaan dana zakat, infaq, dan shadaqah. 48

Untuk melaksanakan pengelolaan zakat menurut UU Nomor 23 Tahun 2011 Pasal 5 ayat (1) adalah pemerintah membentuk BAZNAS. Pada ayat (3) BAZNAS merupakan lembaga pemerintah nonstructural yang bersifat mandiri dan bertanggung jawab kepada Presiden melalui Menteri.

\section{Badan Amil Zakat (BAZ)}

Menurut Keputusan Menteri Agama Nomor 581 tahun 1999 Pasal 1 sub (1) yang dimaksud dengan BAZ adalah organisasi pengelola zakat yang dibentuk oleh pemerintah terdiri dari unsur masyarakat dan pemerintah dengan tugas mengumpulkan, mendistribusikan, dan mendayagunakan zakat sesuai dengan ketentuan agama.49

Untuk memudahkan pelayanan kepada masyarakat dibentuk Unit Pengumpulan Zakat (UPZ) yaitu, suatu oranisasi yang dibentuk oleh BAZ di semua tingkatan dengan tugas untuk melayani muzakki yang menyerahkan zakatnya. Pembentukan UPZ ini dilakukan pada instansi/lembaga pemerintah dan perusahaan swasta di semua tingkatan. Sedangkan untuk BAZ Kecamatan dibentuk pula UPZ di tiap-tiap desa/kelurahan. Tugas UPZ adalah untuk melakukan pengumpulan zakat, infaq, shadaqah, hibah, wasiat, waris dan kafarat di unit masing-masing dengan menggunakan formulir yang di buat oleh BAZ dan menyetorkan hasilnya kepada bagian pengumpulan Badan Pelaksana BAZ. ${ }^{50}$

Kewajiban yang harus dilaksanakan oleh BAZ yang telah terbentuk secara resmi adalah ;

48 Hertanto Widodo dan Teten Kustiawan, Akuntansi dan Manajemen Keuangan untuk Organisasi Pengelolaan Zakat, (Jakarta : Institut Manajemen Zakat, 2011), hal 6

49 Peraturan Pemerintah Nomor 14 Tahun 2011 tentang Pelaksanaan UU Nomor 23 Tahun 2011, Pasal 1 ayat (2)

${ }^{50}$ Keputusan Direktur Jenderal Bimbingan Masyarakat Islam dan Urusan Haji Nomor D/291 Tahun 2013 tentang Pedoman Teknis Pengelolaan Zakat, Pasal 9 Ayat (8). 
a) Segera melakukan kegiatan sesuai program kerja yang telah dibuat.

b) Menyusun laporan tahunan termasuk laporan keuangan.

c) Mempublikasikan laporan keuangan yang telah diaudit oleh akuntan publik tau lembaga pengawas pemerintah yang berwenang melalui media sesuai dengan tingkatannya, selambatlambatnya enam bulan setelah tahun buku berakhir.

d) Menyerahkan laporan tahunan tersebut kepada pemerintah dan Dewan Perwakilan Rakyat sesui dengan tingkatannya.

e) Merencanakan kegiatan tahunan.

f) Mengutamakan pendisribusian dan pendayagunaan dana zakat yangtelah diperoleh dari daerah masing-masing sesuai dengan tingkatannya.

Apabila BAZ tidak melaksanakan kewajiban tersebut diatas maka dapat diadakan peninjauan ulang terhadap keberadaan BAZ tersebut dengan melalui mekanisme sebagai berikut : 1) Pemberian peringatan tertulis sebanyak maksimal tiga kali oleh Pemerintah yang membentuknya. 2) Jika setelah diberikan peringatan tiga kali dan tidak ada perbaikan, maka pembentukan BAZ dengan susunan pengurus yang baru, sesuai mekanisme yang berlaku.

Tugas pokok BAZ adalah mengumpulkan dana zakat dari muzakki baik perorangan maupun badan, yang dilakukan oleh bagian pengumpulan atau melalui UPZ. Selain zakat, BAZ dapat menerima infaq, shadaqah, hibah, wasiat dan kafarat. Terhadap setiap zakat yang diterima, BAZ wajib menerbitkan bukti setoran sebagai tanda terima. Sedangkan bukti setoran zakat yang sah harus mencantumkan hal-hal sebagai berikut :

1. Nama, alamat, dan nomor lengkap pengesahan BAZ (bagi LAZ nomor lengkap pengukuhan LAZ).

2. Nomor urut bukti setoran.

3. Nama, alamat muzakki, dan Nomor Pokok Wajib Pajak (NPWP) apabila zakat penghasilan yang dibayarkan dikurangkan dari Penghasilan Kena Pajak Penghasilan.

4. Jumlah zakat atas penghasilan yang disetorkan dalam angka dan huruf serta dicantumkan tahun haul. 
5. Tanda tangan, nama, jabatan petugas BAZ atau LAZ, tanggal penerimaan dan stempel BAZ atau LAZ.

Bukti setoran tersebut kemudian dibut rangkap tiga dengan rincian sebagai berikut :

1. Lembar 1 (asli) diberikan kepada muzakki yang dapat digunakan sebagai bukti pengurangan Penghasilan Kena Pajak Penghasilan.

2. Lembar 2 diberikan kepada BAZ atau LAZ sebagai arsip.

3. Lembar 3 digunakan sebagai arsip Bank Penerima jika zakat disetor melalui bank.

Penghitungan zakat dapat dilakukan sendiri oleh muzakki atas harta dan kewajiban zakatnya berdasarkan ketentuan hukum Islam. Dalam hal muzakki mengalami kesulitan untuk melakukan penghitungan, maka BAZ ataupun LAZ dapat membantu muzakki dalam melakukan penghitugan.

Zakat yang telah terkumpul kemudian disalurkan kepada yang berhak menerimanya sesuai dengan ketentuan hukum Islam. Penyaluran zakat tersebut harus bersifat hibah (bantuan). Penyaluran batuan zakat tersebut dapat bersifat :

a. Bantuan Sesaat

Yaitu membantu mustahiq dalam menyelesaikan atau mengurangi masalah yang sangat mendesak/darurat.

b. Bantuan Pemberdayaan

Yaitu membantu mustahiq untuk meningkatkan kesejahteraannya, baik secara perorangan maupun kelompok melalui program atau kegiatan yang berkesinambungan.

Penyaluran dana zakat tersebut harus memperhatikan skala prioritas kebutuhan mustahiq di wilayah masing-masing kecuali penyaluran zakat yang dilakukan oleh BAZ Nasional dapat diberikan kepada mustahiq di seluruh Indonesia. Dalam hal tertentu, BAZ dapat menyalurkan dana zakat keluar wilayah kerjanya, dengan mengadakan koordinasi terlebih dahulu dengan BAZ yang berada di wilayah tersebut.

Mengenai pengawasan terhadap kinerja BAZ, dilakukan secara internal oleh Komisi Pengawas BAZ sesuai dengan tingkatan 
masing-masing serta secara eksternal oleh pemerintah dan masyarakat. Dalam melakukan pengawasan tersebut, Komisi Pengawas dapat meminta bantuan kepada akuntan publik. Ruang lingkup pengawasan meliputi keuangan, kinerja BAZ dan pelaksanaan peraturan perundang-undangan serta prinsip-prinsip syari'ah. Pengawasan tersebut dilakukan terhadap rancangan program kerja, pelaksanaan program kerja pada tahun berjalan dan setelah tahun buku berakhir. Kemudian hasil pengawasan tersebut di sampaikan kepada Badan Pertimbangan untuk dibahas tindak lanjutnya.

Laporan pelaksanaan tugas BAZ disampaikan BAZ kepada pemerintah dan Dewan Perwakilan Rakyat sesuai tingkatan masingmasing. Materi laporan tersebut meliputi semua kegiatan yang telah dilakukan oleh BAZ seperti berbagai kebijakan yang telah diputuskan dan dilaksanakan serta laporan tentang pengumpulan dan pendayagunaan dana zakat.

2. Lembaga Amil Zakat (LAZ)

Menurut UU no 23 tahun 2011 pasal 17 untuk mebantu BAZNAS dalam pelaksanaan pengumpulan, pendistribusian, dan pendayagunaan zakat, masyarakat dapat membentuk LAZ, yang dimaksud dengan Lembaga Amil Zakat adalah institusi pengelolaan zakat yang sepenuhnya dibentuk atas prakarsa masyarakat dan oleh masyarakat yang bergerak dibidang da'wah, pendidikan, sosial dan kemaslahatan umat Islam. Lembaga Amil Zakat (LAZ) harus mendapat pengukuhan dari pemerintah sesuai dengan tingkatan masing-masing yaitu :

a. Nasional, dikukuhkan oleh Menteri Agama

b. Daerah propinsi, dikukuhkan oleh Gubernur atas usul kepala Kantor Wilayah Departemen Agama Propinsi

c. Derah kabupaten, dikukuhkan oleh Bupati atau Walikota atas usul dari Kepala Kantor departemen Agama Kabupaten atau kota

d. Daerah Kecamatan, dikukuhkan oleh Camat atas usul dari Kepala Kantor Urusan Agama Kecamatan

Untuk dapat dikukuhkan, maka LAZ harus memenuhi persyaratan dengan melampirkan pernyataan, sebagai berikut :

a. Akte pendirian (berbadan hukum). 
b. Memiliki data muzakki dan mustahiq.

c. Memiliki program kerja.

d. Memiliki perbukuan.

e. Bersedia untuk diaudit.

Setiap LAZ harus mendapatkan pengukuhan dari pemerintah, karena hanya LAZ yang telah dikukuhkan saja yang diakui bukti setoran zakatnya sebagai pengurang penghasilan kena pajak dari muzakki yang membayar dananya. Setelah mendapat pengukuhan dari pemerintah, LAZ memunyai beberapa kewajiban, yaitu :

a. Segera melakukan kegiatan sesuai dengan program kerja yang telah dibuat.

b. Menyusun laporan, termasuk laporan keuangan.

c. Mempublikasikan laporan keuangan yang telah diaudit melalui media massa.

d. Menyerahkan laporan kepada pemerintah.

Sebagaimana BAZ, LAZ yang tidak melaksanakan kewajiban seperti diatas, maka pemerintah akan menyampaikan peringatan secara tertulis sebanyak tiga kali. Dan apabila setelah diperingatkan LAZ tersebut tidak ada perbaikan maka pengukuhannya dapat ditinjau ulang bahkan dapat dilakukan pencabutan pengukuhan. Akibat dari pencabutan pengukuhan tersebut adalah :

a. Hilangnya hak pembinaan, perlindungan, dan pelayanan dari Pemerintah.

b. Tidak diakuinya bukti setoran pajak yang dikeluarkan sebagai pengurang penghasilan kena pajak.

c. Tidak dapat melakukan pengumpulan dana zakat.

Cara penghimpunan zakat di BAZ Nganjuk dengan cara menerima setoran dari instansi-instansi pemerintah ataupun swasta yang di koordinir oleh satu orang yang di sebut UPZ. Penghimpunan zakat di kantor BAZ Nganjuk di laksanakan setiap hari jam kenja mulai hari Senin sampai dengan Jum 'at akan tetapi dilaksanakan satu bulan sekali atau dua bulan sekali atau tiga bulan sekali.Jenis zakat yang di kumpulkan adalah zakat profesi, zakat mal dan zakat fitrah.

Baik buruknya pengelolaan zakat sangat tergantung pada amil zakat yang mengelola zakat tersebut. Dalam Keputusan Dirjen 
Bimbingan Masyarakat Islam dan Urusan Haji Nomor D/291 Tahun 2000 Pasal 4 ayat (3) menyebutkan bahwa pengurus Badan Amil Zakat Kabupaten atau Kabupaten harus memiliki kriteria yaitu amanah, mempunyai visi dan misi, berdedikasi, profesional, berintegritas tinggi dan mempunyai program kerja. Sedangkan Yusuf Qardawi, dalam bukunya hukum zakat mengemukaan beberapa syarat yang harus dipenuhi oleh sebuah amil zakat. Syarat-syarat tersebut yang pertama Muslim, syarat ini menjadi syarat utama bagi amil zakat karena zakat merupakan urusan kaum muslim. Sebagai seorang muslimlah yang harus menangani urusan tersebut. Tetapi dalam hal ini dimungkinkan bagi non muslim untuk dilibatkan dalam pengelolan zakat. Namun keterlibatan non muslim itu hanya sebatas pada bagianbagian tertentu saja yang tak penting. Seperti misalnya : sopir atau penjaga gudang. Untuk yang berkaitan dengan pemungutan dan pembagian zakat harus dipegang oleh muslim.

Kedua, Muallaf yakni orang dewasa yang sehat akal fikirannya. Syarat ini dimaksudkan agar amil zakat tersebut dapat melaksanakan dengan baik. Ketiga, jujur. Syarat ini untuk menghindari tindakan sewenang-wenang amil zakat terhadap hak fakir miskin karena mengikuti hawa nafsunya atau untuk mencari keuntungan semata. Orang yang jujur akan berusaha menjaga amanat yang telah diberikan kepadanya. Sehingga ia akan menghindari berbuat zalim kepada pemilik harta.

Keempat, memahami Hukum Zakat. Para ulama mensyaratkan petugas zakat faham terhadap hukum zakat, apabila ia diserahi urusan umum. Sebab bila ia tidak mengetahui hukum, tidak mungkin mampu melaksanakan pekerjaan dan akan lebih banyak berbuat kesalahan, masalah zakat membutuhkan pengetahuan tentang harta yang wajib dizakati dan yang tidak wajib dizakati. Juga urusan zakat memerlukan ijtihad terhadap masalah yang timbul untuk diketahui hukumnya. Apabila pekerjaan itu menyangkut bagian tertentu mengenai urusan pelaksanaan, maka tidak diisyaratkan memiliki pengetahuan tentang zakat, kecuali sekedar yang menyangkut tugasnya. 
Kelima, mampu untuk melaksanakan tugas. Petugas zakat hendaknya memenuhi syarat untuk dapat melaksanakan tugasnya dan sanggup untuk memikul tugas itu. Kejujuran saja belum cukup bila tidak disertai dengan kekuatan dan kemampuan untuk bekerja. Keenam merdeka, pendapat ini dikemukakan oleh sebagian ulama. Dasar hukum yang mereka kemukakan adalah satu hadist riwayat Ahmad dan Bukhor, yaitu Rasulullah SAW bersabda : "Dengarkanlah oleh kalian dan taatilah walaupu yang memerintahkan kamu seorang budak yang rambutnya keriting seperti kismis. Oleh budakpun urusan dapat selesai, karenanya ia sama dengan orang yang merdeka".

Secara umum kriteria seorang amil zakat yang diatur dalam Keputusan Menteri Agama RI tersebut sama dengan kriteria amil zakat menurut Yusuf Qardawi. Perbedaannya adalah Yusuf Qardawi mensyaratkan bahwa seorang amil zakat adalah muslim. Namun syarat tersebut tidaklah mutlak, yaitu dapat dimungkinkan seorang non muslim untuk dapat terlibat dalam pengelolaan zakat. Hanya saja penempatannya terbatas pada posisiposisi tertentu yang tidak terlalu penting.

Dalam keputusan Menteri Agama RI tersebut tidak ada syarat khusus yang menyatakan bahwa amil zakat harus seorang muslim. Hal ini disebabkan karena masalah zakat termasuk masalah ibadah, sehingga merupakan urusan kaum muslim. Oleh karena itu otomatis orang-orang yang mengurus pengelolaannya adalah orang-orang muslim.

Sedangkan syarat amil zakat yang dikemukakan oleh Yusuf Qardawi ada yang tidak relevan dengan perkembangan saat ini. Syarat tersebut adalah syarat yang menyebutkan bahwa amil zakat adalah orang yang merdeka. Syarat tersebut dikemukakan berdasarkan keadaan pada zaman Nabi Muhammad SAW, dimana pada saat itu masih ada perbudakan.

\section{Sistem Pengumpulan Zakat di Kantor BAZ Kabupaten Nganjuk}

Mekanisme pengelolaan zakat sangat dipengaruhi oleh maksimal atau tidaknya proses pengumpulan zakat.Umat islam hampir 
dipastikan mengerti bahwa menunaikan zakat merupakan kewajiban.Hanya saja zakat yang sangat dikenal di masyarakat adalah zakat fitrah yang di keluarkan pada bulan ramadhan.Sedangkan zakat harta belum menjadi sumber ekonomi yang memadai terbukti dari minimnya pencapaian potensi zakat di Indonesia. Prinsip penuaian zakat juga berdasarkan pada kesadaran setiap muslim. Penyul;uhan, komunikasi, dan kegiatan fundraising zakat menjadi tugas lembaga pengelola zakat agar terbuka motivasi setiap mslim untuk menunaikan zakatnya.

Sebagaimana yang telah diatur didalam Undang - Undang No 23 Tahun 2011 Pasal 21 ayat (1) bahwa dalam rangka pengumpulan zakat, muzakki melakuan penghitungan sendiri atas kewejiban zakatnya. Pada ayat (2)bahwa dalam hal tidak dapat menghitung sendiri kewajiban zakatnya,muzaki dapat meminta bantuan BAZNAS. ${ }^{51}$

Selanjutnya dalam pengumpulan zakat dari harta muzakki yang berada di bank, BAZ dapat bekerjasama dengan bank atas permintaan muzakki yaitu dengan memberikan kewenangan kepada petugas bank untuk memungut zakat harta simpanan muzakki.

Sebagai tindak lanjut dari pembentukan BAZ di Kabupaten Nganjuk, dan sesuai dengan Keputusan Direktur Jenderal Bimbingan Masyarakat dan Urusan Haji Nomor D/291 Tahun 2013 tentang Pedoman Tekhnis Pengelolaan Zakat, Pasal 9 ayat (4) bahwa Badan Amil Zakat Daerah Kabupaten/Kabupaten dapat membentuk Unit Pengumpul Zakat (UPZ) pada instansi/lembaga pemerintah daerah, BUMN, BUMD, dan perusahaan swasta yang berkedudukan di Kabupaten/Kabupaten. UPZ tersebut dibentuk berdasarkan Surat Keputusan dari Kepala masing-masing instansi tersebut. UPZ tersebut bertugas mengumpulkan zakat dari pegawai masing-masing instansi tersebut kemudian menyetorkannya kepada BAZ Kabupaten Nganjuk. Zakat yang dikumpulkan tersebut berupa zakat profesi dan mekanisme pengumpulannya adalah dengan memotong 2,5 \% dari gaji yang diterima per bulan. Namun pemotongan gaji itu berdasarkan surat

${ }^{51}$ UU No. 23 tahun 2011 tentang Pengelolaan Zakat 
pernyataan / kuasa yang ditandatangani oleh pegawai yang bersangkutan. ${ }^{52}$

Selama ini ruang lingkup BAZ Kabupaten Nganjuk masih terbatas pada pengumpulan zakat, infaq dan shadaqah. Belum adanya masyarakat yang membayarkan harta selain zakat, infaq dan shadaqah melalui BAZ dikarenakan masyarakat masih belum memahami bahwa BAZ dan UPZ juga menerima pembayaran hibah, wasiat, waris dan karafat. Hal ini disebabkan juga dengan adanya perubahan nama dari BAZIS menjadi BAZ menimbulkan kebingungan dalam masyarakat. Dengan perubahan nama tersebut seolah-olah ruang lingkup kewenangan BAZ menjadi semakin sempit, yaitu hanya terbatas pada pengelolaan zakat saja tidak neliputi harta yang lain.

Untuk meningkatkan kesadaran masyarakat BAZ Kabupaten Nganjuk saat ini menerapkan setrategi dalam penghimpunan zakat antara lain $:^{53}$

1. Mensosialisasikan kepada masyarakat tentang arti pentingnya berzakat

2. Mensosialisasikan arti pentingnya zakat lewat media cetak maupun elektronik (radio, majalah, koran, stiker)

3. Berusaha memberikan pemahaman muzakki tentang hikmah kewajiban zakat sebagai rukun islam yang disejajarkan dengan sholat dan puasa

4. Memberikan kepercayaan kepada muzakki bahwa berzakat melalui BAZDA akan menjamin pemerataan dan mendorong kearah pemberdayaan masyarakat secara signifikan

Mengenai distribusi hasil penerimaan zakat yang telah terkumpul, telah diatur dalam Pasal 25 Undang-Undang Pengelolaan Zakat. Dalam Pasal 25 tersebut disebutkan bahwa Zakat wajib didistribusikan kepada mustahik sesuai dengan syariat Islam, ${ }^{54}$ yaitu

${ }^{52}$ Keputusan Direktur Jenderal Bimbingan Masyarakat dan Urusan Haji Nomor D/291 Tahun 2013 tentang Pedoman Tekhnis Pengelolaan Zakat

${ }^{53}$ Drs. H. Achmad Hidayat, Model-model Kreatif Pengelolaan Zakat, BAZ Kab Nganjuk

Zakat Pasal 25

${ }^{54}$ Undang-Undang Nomor 23 Tahun 2011 tentang Pengelolaan 
harus memenuhi delapan ashnaf. Delapan ashnaf tersebut meliputi fakir, miskin, amil, muallaf, riqab, ghorim, sabilillah, dan ibnusabil.

Dalam Pasal 26 ayat Undang-Undang Pengelolaan Zakat disebutkan bahwa Pendistribusian zakat, sebagaimana dimaksud dalam Pasal 25, dilakukan berdasarkan skala prioritas dengan memperhatikan prinsip pemerataan , keadilan, dan kewilayahan. ${ }^{55}$ Sedangkan mengenai persyaratan dan prosedur distribusi hasil pengumpulan zakat diatur dalam Peraturan Pemerintah No. 14/2014 tentang Pelaksanaan Undang-Undang Pengelolaan Zakat Pasal 25 dan Pasal 26. Distribusi hasil pengumpulan zakat harus memenuhi syarat sebagai berikut : ${ }^{56}$

a. Hasil pendataan dan penelitian kebenaran musthahig delapan ashnaf yaitu: fakir, miskin, amil, muallaf, riqab, ghorim, sabilillah dan ibnussabil.

b. Mendahulukan orang-orang yang paling tidak berdaya memenuhi kebutuhan dasar secara ekonomi dan sangat memerlukan bantuan.

c. Mendahulukan mustahiq dalam wilayahnya masing-masing.

Hasil pengumpulan zakat yang dapat didayagunakan untuk usaha yang produktif dengan syarat a) Apabila pendayagunaan zakat untuk delapan ashnaf telah terpenuhi dan ternyata masih terdapat kelebihan. b) Terdapat usaha-usaha nyata yang berpeluang menguntungkan. d) Mendapat persetujuan tertulis dari Dewan Pertimbangan. Setelah memenuhi persyaratan tersebut, distribusi hasil pengumpulan zakat untuk usaha produktif harus melalui prosedur sebagai berikut :

a. Melaksanakan studi kelayakan.

b. Menetapkan jenis usaha produktif.

c. Melakukan bimbingan dan penyuluhan.

d. Melakukan pemantauan, pengendalian dan pengawasan.

e. Mengadakan evaluasi

f. Memberi laporan.

${ }^{55}$ Ibid. Pasal 16 Ayat (2)

56 Peraturan Pemerintah Nomor 14/2014 tentang Pelaksanaan Undang-Undang Pengelolaan Zakat, Pasal 25-26

Volume 7 No.1 Januari 2020 
Hasil penerimaan selain zakat, seperti hasil penerimaan infaq dan shadaqah, hibah, wasiat, waris dan karafat yang terkumpul di BAZ didayagunakan untuk usaha produktif. Di Kabupaten Nganjuk, distribusi hasil penerimaan zakat telah memenuhi delapan ashnaf, sesuai dengan ketentuan agama. Pada umumnya didayagunakan untuk usaha produktif masyarakat. Sebagai contoh, diberikannya pinjaman modal bagi pedagang kecil sebagai usaha modal dan tanpa dikenai bunga.

Sedangkan untuk infaq dan sadaqah didayagunakan untuk usaha produktif sebagai pinjaman modal. Segi positif dari bantuan yang bersifat pinjaman diantaranya adalah si peminjam akan lebih bersemangat dalam berusaha karena ada keharusan untuk mengembalikan pinjaman tersebut dan uang pinjaman yang telah di kembalikan dapat dipinjamkan kembali kepada orang lain. Sebagai contoh yang dilakukan oleh BAZ Kabupaten Nganjuk. Distribusi hasil infaq dan shadaqah yang terkumpul digunakan untuk memberikan pinjaman modal kepada pengusaha industri rumah tangga ataupun pedagang kecil.

\section{Sistem Pendayagunaan Zakat di Kantor BAZ Kebupaten Nganjuk}

Dalam Undang-undang No. 23 Tahun 2011 pasal 27 tentang pendayagunaan zakat yaitu: ayat (1) Zakat dapat didayagunakan untuk usaha produktif dalam rangka penanganan fakir miskin dan peningkatan kualitas umat, ayat (2) Pendayagunaan zakat untuk usaha produktif sebagaimana dimaksud pada ayat (1) dilakukan apabila kebutuhan dasar mustahik telah terpenuhi, ayat (3) Ketentuhan lebih lanjut mengenai pendayagunaan zakat untuk usaha produktif sebagaimana dimaksud pada ayat (1) diatur dalam peraturan Menteri. 57

Dalam pendayagunaan zakat ada 3 prinsip yang perlu di perhatikan yaitu: Diberika kepada delapan asnaf, Manfaat zakat itu

${ }^{57}$ Undang - Undang No.23 Thn 2011 tentang Pengelolaan Zakat 
dapat di terima dan di rasakan manfaatnya, sesuai dengan keperluan mustahiq (konsumtif atau produktif).

Keberhasilan zakat tergantung kepada pendayagunaan dan pemanfaatannya. Walaupun seorangwajib zakat (muzakki) dan mengetahui dan mampu memperkirakan jumlah zakat yang akan dikeluarkan, tidak dibenarkan ia menyerahkannya kepada sembarang orang yang ia sukai.Penyerahan yang benar adalah melilui Badan Amil Zakat.Walaupun demikian kepada Badan Amil Zakat manapun tetap harus mengefektifkan pendayagunaan yang efektif yaitu efektif manfaatnya (sesuai dengan tujuan) dan jatuh pada yang berhak (sesuai dengan nas) secara tepat guna.

Di kantor BAZ Nganjuk pendayagunaan zakat membantu mengurangi dan mengangkat kaum fakir miskin dari kesulitan hidup dan penderitaan mereka juga membantu permasalahan yang di hadapi oleh Ibnu Sabil dan para mustahuq lainnya. Permasalahan mendasar yang dialami oleh usaha kecil adalah masalah permodalan .BAZ kota Nganjuk memberikan modal usaha kepada usaha kecil yang merupakan program zakat yang harus di tunjukkan kepada usaha untuk mengatasi persoalan-persoalan uasaha kecil tersebut.

Program pendayagunaan zakat di Kota nganjuk untuk memperdayakan ekonomi dengan langkah - langkah sebagai berikut;

1. Pendaftaran calon penerima bantuan

2. Survey kelayakan

3. Strategi Pengelompokan

4. Pendampingan

5. Pembinaan secara berkala

6. Melibatkan mitra pihak ketiga

7. Pengawasan ,Kontrol dan Evaluasi

Santunan kepada fakir miskin atau bantuan kepada janda miskin memang menjadi salah satu program yang gunanya untuk membantu meringankan beban ekonomi mereka. Program bantuan ini dilaksanakan setiap bulan. 


\section{Kesimpulan}

Hasil penelitian menunjukkan bahwa pengumpulan zakat di BAZ Kabupaten Nganjuk sebagaimana yang diatur dalam Undang Undang No 23 Tahun 2011 Pasal 21 ayat (1) bahwa dalam rangka pengumpulan zakat, muzaki melakukan penghitungan sendiri atas kewajiban zakatnya. BAZ dengan cara menerima atau mengambil dari muzakki atas dasar pemberitahuan muzakki. Namun dalam pelaksanaan zakat di BAZ Kabupaten Nganjuk dilakukan dengan cara mengumpulkan zakat yang sudah terkumpul di UPZ-UPZ yang ada di tiap-tiap instansi, kemudian disetorkan ke BAZ Kabupaten Nganjuk untuk di distribusikan. Pendistribusian zakatdi BAZ Nganjuk sebagaimana yang diatur dalam Undang - Undang No 23 tahun 2011 Pasal 25 yaitu Zakat wajib didistribusikan kepada mustahik sesuai dengan syariat Islam.

Sedangkan Pendayagunaan zakat di BAZ Kabupaten Nganjuk, sebagaimana yang diatur dalam Undang-Undang No 23 tahun 2011 tentang Pengelolaan Zakat pasal 27 Ayat (1) Zakat dapat didayagunaan untuk usaha produktif dalam rangka penanganan fakir miskin dan peningkatan kwalitas umat. Pada umumnya didayagunakan untuk usaha produktif masyarakat. Sebagai contoh, diberikannya pinjaman modal bagi usaha kecil sebagai usaha modal dan tanpa dikenai bunga.

\section{Saran}

Dengan melihat proses pelaksanaan zakat di BAZ Kabupaten Nganjuk maka penulis dapat mengajukan saran-saran sebagai berikut :

1. Perlu menigkatkan koordinasi antar lembaga mitra BAZ, Organisasi Pengelola Zakat di Kabupaten Nganjuk, baik BAZ tingkat Kabupaten, BAZ tingkat Kecamatan maupun LAZ yang ada di Kabupaten Nganjuk. Koordinasi tersebut terutama dalam hal pendayagunaan harta zakat, infaq dan shadaqah yang terkumpul. Sehingga penyalurannya akan lebih merata dan tidak menumpuk pada suatu daerah saja. 
2. BAZ Kabupaten Nganjuk diharapkan dapat mempertahankan propesionalitas dan transparansinya dalam pendistribusian zakat, agar zakat bener-benar dinikmati oleh orang-orang yang berhak menerimanya. Juga diharapkan kedepanya dapat lahir programprogram yang lebih efektif dalam upaya membangun ekonomi kerakyatan khususnya masyarakat Nganjuk mengenai program ekonomi, Pihak BAZ Nganjuk hendaknya benar-benar menyalurkan dana zakat khususnya distribusi dalam program ekonomi pemberian mutlak kepada mustahiq tanpa dinyatakan sebagai dana pinjam.

3. Dalam meningkatkan pendayagunaan zakat kepada masyarakat. Maka BAZ Nganjuk perlu menambah pinjaman modal guna menambah usaha produktif masyarakat.

\section{Daftar Pustaka}

Armin Mansyur, Pengelolaan Zakat dan Permasalahannya di Indonesia, Direktorat Urais Departemen Agama : 2010)

Abdul Malik Ar Rohman, Zakat 1001 Masalah dan Solusinya, (Bandung Pustaka Cerdas, 2013)

Hafidhuddin Didin, Panduan Praktis Tentang Zakat, Infak dan Sedekah, (Jakarta, Gema Insani, 2011)

Departemen Agama, Al Qur`an dan Terjemahannya, (Semarang : CV. Al Waad, 2011)

Departemen Agama, Pedoman Zakat 9 Seri, (Jakarta : Proyek Pembinaan Zakat dan Wakaf,2011)

Hadi, Sutrisno, Metodologi Research, Jilid I, cet. Ke-24, (Yogyakarta : Andi Offset, 2013)

Husnan, Ahmad, Zakat menurut Sunnah dan Zakat Model Baru, (Jakarta : Pustaka Al Kautsar, 2013)

Koentjaraningrat, Metode-metode Penelitian Masyarakat, (Jakarta : PT. Gramedia, 2013)

N.A. Baiquni, dkk, Kamus Istilah Agama Islam Lengkap, (Surabaya : Indah, 2013)

Qardawi, Yusuf, Hukum Zakat, (Bogor : Litera Antar Nusa, 2011) 
Jurnal Dinamika Ekonomi Syariah

http://ejurnal.iaipd-nganjuk.ac.id/index.php/es

p-ISSN: 2654-3567

Qardawi, Yusuf, Kiat Sukses Mengelola Zakat, diterjemahkan oleh Asmuni Solihan Zamakhayari, (Jakarta : Media Dakwah, 2013)

Widodo, Hertanto dan Teten Kurniawan, Akutansi dan Manajemen Keuangan untuk Organisasi Pengelola Zakat, (Jakarta : Institut Manajemen Zakat,2011)

Undang - Undang Dasar 1945

Undang-Undang No 23 Tahun 2011 Tentang Pengelolaan Zakat 